\title{
Isu Laut Tiongkok Selatan: Negara-negara ASEAN Terbelah Menghadapi Tiongkok
}

\author{
Arief Bakhtiar Darmawan \& Lady Mahendra \\ Universitas Jenderal Soedirman \& Waseda University
}

\begin{abstract}
ABSTRAK
Artikel inibertujuan untukmenganalisis strateginegara-negaraanggotaASEAN dalam menghadapi Tiongkok terkait sengketa Laut Tiongkok Selatan (LTS). Kawasan LTS merupakan arena bagi kompetisi kekuatan antara Tiongkok, Filipina, Vietnam, Malaysia, dan Brunei. Kelima pihak tersebut bersaing atas kedaulatan di wilayah LTS. Kawasan LTS menjadi menarik bagi beberapa pihak, terutama jika mempertimbangkan nilai strategis bagi kebijakan yang ekspansif. Dalam era kontemporer, kemunculan konflik ini dipandang sebagai masalah yang bisa menyebabkan pergeseran perimbangan kekuatan, yaitu ketika Amerika Serikat berusaha menjaga momen unilateral pasca-Perang Dingin. Meskipun hanya terdapat empat negara ASEAN yang terlibat langsung, adopsi deklarasi mengenai LTS oleh seluruh anggota ASEAN menegaskan bahwa dalam kasus ini ASEAN berusaha berdiri bersama untuk memperlihatkan tujuannya menghadapi agresivitas Tiongkok. Dengan menggunakan perspektif realisme struktural sebagai pisau analisis, tendensi strategi negara-negara anggota ASEAN yang berbeda dapat dipahami dari penjelasan mengenai motif-motif di belakangnya. Filipina dan Vietnam cenderung pada strategi perimbangan kekuatan menghadapi Tiongkok. Kamboja, Laos, dan Myanmar memperlihatkan indikasi untuk mengikuti gerbong Tiongkok, sementara negara-negara lain tidak memilih di antara dua strategi tersebut.
\end{abstract}

Kata-kata kunci: sengketa Laut Tiongkok Selatan, ASEAN, Tiongkok, realisme struktural, strategi perimbangan dan pemihakan

This paper aims to analyze the strategies of each ASEAN member states towards China related to the dispute in the South China Sea (SCS). SCS area is becoming a platform of power competition between China, the Philippines, Vietnam, Malaysia, and Brunei. Five parties mentioned above are competing over sovereignty in certain areas of the SCS. SCS area became interesting to certain parties, considering its strategic value for expansive policy. In the contemporary era, the rise of this conflict perceived as a problem which caused by shifting balance of power, that happened when the U.S. sought to preserve its unilateral moment after the end of cold war. This lead to vacuum of power situation in the Southeast Asia, thus encourage China to build up presence in the dispute area. Even though there are only four ASEAN countries that directly involved, however the adoption of the Declaration on the SCS by all ASEAN member countries, asserted that in this case ASEAN is standing together to show their objections of China's aggressiveness. With structural realism perspective as the analysis tool, tendencies of ASEAN member states' different strategies are understandable by the explanation about motives behind it. Which Philippines and Vietnam tend to leaning towards balancing strategy against China. Cambodia, Laos, and Myanmar indicate towards bandwagoning strategy with China, while the rest of the members did not show tendencies of leaning either ways.

Keywords: South China Sea dispute, ASEAN, China, structural realism, balancing and bandwagoning strategy 
ASEAN (Association of Southeast Asian Nations) merupakan organisasi regional yang memiliki keanggotaan dengan latar belakang sosio-kultural dan orientasi politik yang beragam (Acharya 2017, 28-29). Dalam KTT ke19 ASEAN di Bali pada tahun 2011, Presiden Indonesia Susilo Bambang Yudhoyono menyebut ASEAN sebagai "komunitas yang beragam" (Kementrian Luar Negeri RI 2011). Menurut Bruce Russet (1967), organisasi kawasan setidaknya harus memiliki lima karakteristik, seperti:

(1) kemiripan sosio-kultural; (2) kemiripan sikap politik atau perilaku eksternal; (3) keanggotaan yang sama dalam institusi; (4) interdependensi ekonomi; serta (5) memiliki kedekatan geografis. Berdasarkan karakteristik tersebut, ASEAN dianggap terlalu heterogen sebagai suatu organisasi kawasan. Selain itu, orientasi politik negara-negara anggotanya pun berbeda-beda. Sementara dalam hal ekonomi, antarnegara ASEAN memiliki perbedaan GNP per kapita yang mencolok dan masih lebih tergantung dengan negara besar di luar kawasan daripada interdependensi ekonomi antaranggota (IMF, 2016). Di antara lima karakteristik Russet, hanya keanggotaan institusi dan kedekatan geografis ASEAN-lah yang memenuhi karakteristik suatu organisasi kawasan.

Dengan heterogenitas yang tinggi tersebut, ASEAN masih terus menghadapi isu Laut Tiongkok Selatan (LTS) yang sampai saat ini belum memiliki jalan sepakat antarpihak yang terlibat. Posisi LTS sebagai jalur perairan utama dalam kebanyakan ekspedisi laut, yang juga berada di antara negara-negara destinasi perdagangan dan memiliki potensi sumber daya minyak, menjadi daya tarik tersendiri bagi sebagian masyarakat internasional untuk turut terlibat di area tersebut (Kaplan 2011, Watherbee 2005, Zhiguo 2005). Kawasan Laut Tiongkok Selatan merupakan jalur strategis pelayaran yang enam kali lebih padat dan lebih sibuk daripada pelayaran di Terusan Suez dan 17 kali lebih padat daripada Terusan Panama (Kaplan 2011). Mengenai potensi sumber daya alam, menurut perkiraan Tiongkok, LTS memiliki kandungan minyak kira-kira 105-213 miliar barrel. Sementara menurut U.S. Geological Survey, kandungannya kira-kira 28 miliar barrel (Weatherbee 2005, 134). Hingga kini, sengketa LTS semakin menarik berbagai pihak yang memiliki kepentingan, baik bagi negara pengklaim maupun kekuatan-kekuatan maritim eksternal yang memandang LTS sebagai jalur laut yang esensial.

Meski bukan termasuk kekuatan maritim yang berpengaruh di kawasan, negara-negara ASEAN, yakni Filipina, Vietnam, Malaysia, dan Brunei mulai turut terlibat dalam persengketaan wilayah teritorial LTS bersama dengan Tiongkok. Berbagai alasan menjadi dasar klaim pihak-pihak 
tersebut. Secara garis besar, pihak-pihak yang terlibat langsung melakukan klaim atas dasar historis dan UNCLOS 1982. Tiongkok, Taiwan, Vietnam, dan Filipina melakukan klaim atas dasar historis. Vietnam, Filipina, Malaysia, dan Brunei Darussalam melakukan klaim atas dasar UNCLOS 1982. Namun dari segi kekuatan, keempat negara pengklaim dari ASEAN terlihat kurang memadai untuk dapat memenangkan persaingan terhadap Tiongkok. Melihat respon dari tingkat regional ASEAN, muncul pertanyaan mengenai strategi ASEAN dalam menghadapi Tiongkok pada sengketa LTS. Ketika mempertimbangkan tingginya heterogenitas dalam keanggotaan ASEAN sendiri, maka menjadi penting untuk menganalisis lebih dalam mengenai bagaimana heterogenitas ASEAN mempengaruhi strategi dalam menghadapi isu LTS.

Tulisan ini hendak membahas perbedaan strategi negara-negara anggota ASEAN dalam menghadapi Tiongkok di LTS yang kemudian membentuk strategi ASEAN secara kelembagaan. Isu ini dipilih untuk diangkat ke permukaan karena, meski memiliki kapasitas yang relatif tertinggal dibandingkan Tiongkok, empat negara anggota ASEAN terus menampilkan diri sebagai kontestan dalam persaingan kekuasaan di LTS. Hal ini kemudian menempatkan ASEAN di bawah sorotan perhatian masyarakat internasional, mengingat heterogenitas ASEAN merupakan faktor yang kerap dianggap melemahkan ASEAN sebagai organisasi regional. Oleh karena itu, pengaruh heterogenitas negara anggota ASEAN dalam membentuk sikap dan strategi ASEAN secara kelembagaan guna menghadapi Tiongkok di LTS menjadi hal yang menarik untuk diteliti lebih lanjut.

\section{Realisme Struktural sebagai Kerangka Analisis}

Untuk memahami perilaku strategis negara-negara anggota ASEAN dalam menghadapi Tiongkok dalam sengketa LTS, cara pikir realisme struktural akan digunakan sebagai alat bantu untuk menganalisis penelitian ini. Menurut realisme struktural, negara menginginkan kekuasaan karena pengaruh struktur dalam sistem internasional. Dalam realisme struktural, sistem internasional tidaklah bersifat hierarkis, melainkan anarkis, yang memperlihatkan adanya distribusi kekuatan dalam sistem (Lobell 2010, 6651). Sistem internasional yang anarkis tidak menjamin bahwa tidak akan ada negara yang meluncurkan serangan. Maka sangat masuk akal apabila masing-masing negara berusaha memperoleh kekuasaan, setidaknya untuk dapat melindungi diri dari serangan yang dapat terjadi sewaktu- 
waktu (Mearsheimer 2007, 72). Dari pemahaman realisme struktural muncul percabangan-percabangan realisme struktural, yakni realisme ofensif dan realisme defensif.

\section{Realisme Ofensif dan Realisme Defensif}

Realisme ofensif menganggap bahwa keamanan adalah sesuatu yang langka. Sistem internasional yang anarkis menunjukkan ketidakpastian akan intensi tiap-tiap negara yang membuat masing-masing negara harus berkompetisi dalam memperoleh keamanan, yang diartikan sebagai kemampuan untuk bertahan. Maka dari itu muncul pemahaman bahwa menjadi yang paling kuat adalah strategi yang paling aman untuk dapat bertahan. Hal ini mendorong masing-masing negara untuk berlombalomba menerapkan kebijakan yang agresif, seperti kebijakan ekspansi. Dalam realisme ofensif, kebijakan agresif merupakan antisipasi yang paling tepat dari kemungkinan terburuk. Melalui kebijakan agresif inilah negara-negara dengan cara pikir realisme ofensif berupaya mengubah perimbangan kekuatan, memanfaatkan kerugian-kerugian yang dialami negara lain untuk memperoleh kekuatan, serta melemahkan atau menghalangi kompetitor potensial. Dalam pemikiran ini pula, tiap-tiap negara memiliki pikiran yang sama terhadap satu sama lain mengenai ketakutan akan ketergantungan, kerentanan, dan kecurangan, sehingga kompetisi keamanan akan berlangsung terus-menerus secara konstan (Lobell 2010, 6652). ${ }^{4}$

Sementara itu, realisme defensif beranggapan bahwa keamanan merupakan hal yang mudah diwujudkan. Tindakan yang patut dilakukan terkait situasi tersebut ialah memaksimalkan perolehan keamanan, bukan memaksimalkan perolehan kekuatan. Maksimalitas keamanan ini dapat diperoleh melalui kebijakan-kebijakan defensif, yakni berperilaku moderat dan terkendali guna menjaga periimbangan kekuatan (Lobell 2010, 6658). Menurut pemikiran realisme defensif, kompetisi perolehan kekuatan dengan menunjukkan keunggulan masing-masing hanya akan memunculkan dilema keamanan yang mendorong upaya untuk saling mengimbangi. Realisme defensif menganggap bahwa kebijakankebijakan ofensif jarang sekali menguntungkan (Lobell 2010, 6659). Pertama, kebijakan ofensif dapat menjadi senjata makan tuan lantaran menimbulkan perilaku saling mengimbangi. Kedua, nasionalisme modern membuat pengorbanan menjadi jauh lebih besar. Ketiga, perekonomian di era informasi modern membuat tiap-tiap negara menjadi sulit untuk menyerang satu sama lain. Keempat, mengendalikan masyarakat yang 
"politically hostile" akan memakan biaya yang besar.

\section{Strategi Perimbangan dan Pemihakan}

Dua jenis realisme struktural di atas memberikan gambaran tentang bagaimana suatu negara akan bertindak ketika dihadapkan pada munculnya kekuatan asing yang memiliki potensi mengancam. Pertama, strategi menghadapi ancaman yang lebih mengutamakan maksimalisasi kekuatan adalah perimbangan atau balancing, yaitu bergabung dengan pihak yang lebih lemah atau tidak mengancam untuk melawan atau mengimbangi kekuatan besar yang mengancam. Strategi perimbangan dilakukan karena hegemon potensial harus dicegah sebelum menjadi terlalu kuat. Alasan lain adalah karena dengan bergabung dengan negara yang lebih lemah, suatu negara akan memiliki pengaruh besar dalam aliansi, mengingat negara yang lebih lemah membutuhkan lebih banyak asistensi (Walt 2007, 110-111). Melalui dua alasan tersebut, strategi balancing mengedepankan pemeliharaan survival-nya dan peningkatan pengaruh atas negara lain, yang mana keduanya dilakukan untuk tujuan perolehan kekuatan lebih.

Kedua, strategi menghadapi ancaman yang lebih memprioritaskan maksimalisasi keamanan disebut dengan pemihakan atau bandwagoning, yaitu strategi untuk memihak pada kekuatan besar yang mengancam (Walt 1987, 17). Motivasi utama negara dalam menerapkan strategi ini adalah untuk turut memperoleh keuntungan yang didapatkan oleh negara kuat dan menghindari potensi ancaman dari negara kuat tersebut. Kedua motivasi tersebut menunjukkan bahwa perolehan kekuatan bukanlah tujuan utama dari strategi ini. Tanpa kekuatan atau superioritas tertinggi, suatu negara tetap dapat memperoleh keamanan yaitu dengan mendukung preservasi distribusi kekuatan yang telah ada.

Menurut Walt (2007, 110-115), terdapat beberapa situasi yang mempengaruhi dipilihnya kedua strategi di atas. Pertama, terkait faktor kepercayaan. Ketika antara suatu negara dengan negara kuat tidak saling mempercayai, maka untuk melakukan bandwagoning akan sangat beresiko, sehingga balancing akan lebih dirasa tepat. Kedua, terkait faktor kapasitas nasional suatu negara dalam tatanan internasional. Ketika kekuatannya tidak dapat mempengaruhi distribusi kekuatan dalam struktur sistem internasional, maka bandwagoning menjadi pilihan. Namun, bila suatu negara memiliki potensi cukup besar untuk dapat mempengaruhi distribusi kekuatan, maka balancing akan diterapkan. Ketiga, faktor ketersediaan koalisi. Tanpa negara lain untuk diajak 
berkoalisi, suatu negara tidak akan mampu melakukan strategi balancing .

\section{Perilaku Tiongkok dalam Sengketa LTS dan Reaksi Negara- negara Anggota ASEAN}

Dalam isu LTS, Tiongkok merupakan negara yang berusaha meraih dominasi regional, dan di sisi lain, mengimbangi kekuatan pengaruh AS di kawasan (Lee 2017; Darmawan \& Ndadari 2017). Dalam mewujudkan dominasinya, Tiongkok merebut area dan menyerang kapal-kapal negara lain di area sengketa LTS yang tumpang tindih. Pada tahun 1995, Tiongkok menahan kapal Analita dan awaknya dari Filipina selama sepekan. Kapal Analita waktu itu tengah melakukan survei di dekat Gugusan Karang Mischief yang rupanya telah dibangun oleh Tiongkok. Pada tahun 2005, Tiongkok menembaki dan membunuh nelayan Vietnam karena kapal Vietnam dianggap melanggar batas teritorial Tiongkok. Pada tahun 2013, Tiongkok kembali menembakkan peluru ke arah kapal nelayan Vietnam di sekitar Kep. Paracel. Dalam setiap insiden tersebut, Tiongkok selalu mengelak bertanggung jawab dengan berbagai alasan. Tidak hanya itu, pada tahun 2009, lima kapal Tiongkok membayangi dan bermanuver untuk mengusir kapal AS USNS Impeccable yang melakukan patroli rutin di peraritan internasional. Hal itu dianggap AS sebagai ancaman bagi kebebasan navigasi di LTS. Sepanjang tahun 2015 dan tahun berikutnya, Tiongkok diberitakan terus melakukan proyek reklamasi yang mengubah gugusan karang menjadi pulau untuk dibangun berbagai macam infrastruktur.

Dalam pertemuan dan perundingan multilateral mengenai LTS, Tiongkok juga menunjukkan agresivitasnya. Tiongkok bersikeras untuk menolak intervensi negara luar kawasan dan mempertahankan Declaration of Conduct (DOC) yang bersifat ambigu dan tidak mengikat. Dalam Managing Potential Conflicts in the South China Sea (MPCSCS) ke-4 tahun 1993 di Surabaya, Tiongkok menolak usulan Indonesia agar lokakarya tersebut melibatkan AS dan Jepang (Shaohua 2006, 83). Tiongkok terus menundanunda adanya Code of Conduct (COC) yang telah dibuat draf-nya oleh Indonesia. Pada tahun 2012, Tiongkok bahkan mempengaruhi Kamboja yang waktu itu menjadi ketua ASEAN untuk ridak memasukkan isu LTS dalam Konferensi Tingkat Tinggi (KTT) ASEAN (Storey 2013).

Sebelum penulis memaparkan analisis perbedaan pilihan strategi negara anggota ASEAN, penulis akan menguraikan bagaimana reaksi tiap-tiap 
negara anggota ASEAN terhadap tindakan Tiongkok dalam isu sengketa LTS. Uraian ini merupakan dasar untuk melihat bagaimana negaranegara anggota ASEAN tidak satu kata atau terbelah dalam menentukan kebijakan terhadap Tiongkok.

Filipina: diplomasi dan pembangunan kapasitas nasional. Sebagai salah satu negara anggota ASEAN yang terlibat langsung dalam sengketa LTS, Filipina termasuk negara yang sangat menentang keberadaan Tiongkok di area tersebut. Pasca-Perang Dingin berakhir, Filipina bersikeras mempertahankan klaimnya dan mendorong ASEAN untuk bertindak tegas dalam kasus ini. Pada insiden okupasi Gugusan Karang Mischief pada 1995, Filipina dengan kapasitas militer dan ekonominya yang cenderung lemah melakukan upaya melalui pendekatan dari jalur diplomasi. Dengan membangun dialog dengan Tiongkok, mengupayakan dukungan ASEAN dengan selalu menekankan pada negara-negara tetangganya akan pentingnya kesamaan posisi dalam isu ini, dan dukungan ekstraregional melalui perwakilan untuk Amerika Serikat, Jepang, maupun ASEM (Asia-Europe Meeting), Filipina mencapai kesepakatan dengan Tiongkok melalui penandatanganan kode tata berperilaku secara bilateral (Thayer 2011, 10; Chung 2009, 99). Presiden Aquino mengatakan, "We govern ourselves there [Spratly Islands/KIG]. Instead of one country has a bilateral agreement with China and the other has a different bilateral agreement with China. Let's come together as a body. Why do we have to fight or increase all of these tensions when it profits nobody."

Pada insiden Gugusan Karang Mischief ke-2 di tahun 1998, Filipina beralih pada AS lantaran minimnya dukungan kawasan. Filipina memperbolehkan pasukan AS untuk menggunakan fasilitas Filipina dan melatih pasukan Filipina. Latihan pertama antara Filipina dan AS adalah latihan Balikatan yang dilangsungkan pada 2004. Filipina juga membentuk program peningkatan kapasitas militer, yakni The Armed Forces of the Philippines' Capability Upgrade Program (CUP), yang memiliki tiga fase peningkatan kapabilitas dengan jangka waktu pencapaian 18 tahun dimulai dari tahun 2006 (Yeneza 2012, 142-143). Sementara itu, terkait agresivitas Tiongkok yang mulai meningkat sejak akhir tahun 2010, Filipina telah menyampaikan protes terhadap Tiongkok dan meminta pengawalan pasukan patroli pantai dan pasukan angkatan laut Filipina pada setiap aktivitas lepas pantai, seperti eksplorasi minyak dan gas serta pengujian seismik (Thayer 2011).

Vietnam: negara agresor. Dalam sengketa LTS, Vietnam dan Tiongkok 
pernah terlibat perang terbuka pada tahun 1988 yang memakan korban kurang lebih 70 tentara Vietnam. Dalam hal pergerakan militer, Vietnam cenderung lebih cepat bila dibandingkan dengan negara pengklaim ASEAN lainnya. Pada tahun 1999, Vietnam telah menempatkan 700 tentara di 27 bentukan tanah di area sengketa. Berangkat dari situlah Tiongkok memfokuskan strategi pertahanannya kepada Vietnam yang dianggap sebagai agresor diantara negara-negara anggota ASEAN (Lee 1991, 157). Sama halnya dengan Tiongkok, Vietnam tidak menunjukkan keinginan sedikitpun untuk berkompromi perihal batas teritorial (Shoji 2011, 9). The National Boundary Commission of the Vietnamese Ministry of Foreign Affairs mengembangkan situs yang dinamakan "Vietnam's Sovereign Boundaries". Situs tersebut memuat dokumen-dokumen sejarah dari abad ke-18 hingga awal abad 20 yang menjadi bukti dasar klaim Vietnam atas Kepulauan Spratly dan Paracel.

Sebagai negara anggota ASEAN yang paling banyak menguasai pulau di LTS, Vietnam merasa perlu meningkatkan fungsi militer dan pembukaan akses ke pangkalan angkatan laut Cam Ranh Bay (The Associated Press 2010). Bantuan militer dari Rusia juga menjadi salah satu sumber peningkatan kapasitas militer Vietnam. Pada tahun 2009, Vietnam dan Rusia menandatangani pembelian 6 unit kapal selam Kilo-class dan kesepakatan-kesepakatan lain yang mendukung fasilitas pertahanan Vietnam (Shoji 2011, 11). Di dalam negeri, muncul kecaman terhadap tindakan Tiongkok. Pada tahun 2011, misalnya, Vietnam menuduh tentara Tiongkok melakukan pemukulan terhadap kapten penangkapan ikan Vietnam yang memicu aksi demonstrasi anti-Tiongkok. Para demonstran memenuhi Hanoi dan Ho Chi Minh City. Demonstrasi ini bertahan selama 11 kali akhir minggu berturut-turut (Ciorciari \& Weiss 2012).

Indonesia: midwife country. Pada kasus sengketa LTS, menurut Liselotte Odgaard (2003), Indonesia berperan sebagai "midwife country" dalam ASEAN karena sikapnya yang menjaga hubungan baik dengan Tiongkok dan AS, namun tetap waspada dan menekankan perdamaian dan stabilitas. Tanpa ada kepentingan secara langsung di area sengketa, Indonesia tetap berperan aktif mengupayakan resolusi konflik, seperti mengadakan pertemuan koordinasi tahunan MPCSCS sejak tahun 1990 sebagai wadah negara-negara berkonflik untuk berdialog dan mengeksplorasi peluang kerjasama di area sengketa. Adapun kepentingan Indonesia di kasus LTS adalah klaim Tiongkok pada peta sembilan garis putus-putus Tiongkok yang dikhawatirkan mengancam area Kepulauan Natuna. Kekhawatiran tersebut mendorong bergabungnya Indonesia dalam Cooperation Afloat 
Readiness and Training (CARAT), yaitu latihan militer gabungan terbesar di tahun 1996 yang menghubungkan tentara AS, Indonesia, Brunei Darussalam, Malaysia, Singapura, dan Thailand (Weatherbee 2008, 374).

Pada periode kepemimpinannya sebagai chairman ASEAN periode 20112012, Indonesia memberi perhatian cukup besar mengenai konflik LTS. Susilo Bambang Yudhoyono selaku Presiden Indonesia menyatakan bahwa Indonesia akan berusaha mempersuasi Tiongkok agar bersedia untuk mendiskusikan konflik dalam forum multilateral (Thayer 2011, 2829). Menteri Luar Negeri Indonesia Marty Natalegawa pun turut berperan aktif dengan berupaya mengangkat isu ini di pertemuan kawasan maupun internasional (Shoji 2011). Kontribusi Indonesia masih tetap terlihat meski tidak lagi menjabat sebagai chairman ASEAN, yaitu dengan mengambil inisiatif untuk memaparkan draf nol kode tata berperilaku pada bulan September 2012 di sela pertemuan Majelis Umum PBB (Thayer 2013). Setelah memperoleh persetujuan dengan kebulatan suara, untuk penggunaan dokumen ini sebagai basis mendiskusikan kode tata berperilaku dengan Tiongkok, Indonesia berkunjung ke lima ibu kota negara anggota ASEAN, yakni Manila, Hanoi, Bangkok, Phnom Penh, dan Singapura, guna membentuk kesamaan posisi, terutama dalam kode tata berperilaku.

Singapura: keseimbangan ekonomi dan keamanan. Selama ini, Singapura memiliki kekhawatiran bahwa rangkaian tindakan Tiongkok telah melanggar ketentuan United Nations Convention on the Law of the Sea (UNCLOS) 1982, mengganggu stabilitas kawasan, serta mengganggu kebebasan navigasi di area LTS mengingat Selat Malaka merupakan jalur perairan esensial yang kerap dilalui kapal militer, kapal komersil, maupun kapal pengangkut minyak (Djalal 2009, 176). Oleh sebab itu pada Januari 1998, Singapura mengumumkan bahwa kapal induk AS akan diberi akses untuk menggunakan fasilitas pelabuhannya dan terdapat dermaga khusus untuk mengakomodasi kapal induk AS (Buszynski 2003, 353). Pada tahun 2004, Menteri Keamanan dan Pertahanan Singapura Tony Tan menyatakan bahwa Singapura akan memperdalam hubungan kerjasama keamanan dengan AS, diantaranya dengan menyediakan fasilitas di Pangkalan Angkatan Laut Changi yang akan mengakomodasi kapal angkatan laut AS. Angkatan udara AS juga telah memperoleh akses ke Pangkalan Udara Paya Lebar milik Singapura (Vaught \& Morrison 2006, 31). Meski di bidang ekonomi Singapura kerap mendorong ASEAN untuk membangun kerja sama dengan Tiongkok, namun dalam hal keamanan Singapura mendukung keberadaan AS di kawasan. 
Thailand: fleksibilitas dengan orientasi kepentingan nasional. Meski telah melakukan kerja sama strategis di masa krisis Kamboja dan adanya bantuan Tiongkok dalam krisis finansial Asia tahun 1997, Thailand merupakan negara yang tidak begitu mengkhawatirkan pengaruh Tiongkok di kawasan (Baviera 1999, 24). Meski demikian, menurut Vaughn dan Morrison (2006, 28), Thailand tetap membangun hubungan positif dengan AS. Oleh karena itu, dalam isu LTS, Thailand yang tidak memiliki klaim langsung cenderung mengutamakan kepentingan nasionalnya sebagai pertimbangan membangun hubungan dengan kekuatan-kekuatan besar yang berkepentingan di area sengketa. Dalam kasus LTS, Thailand mendorong setiap pihak yang terlibat dalam persengketaan harus menyelesaikan masalah secara damai dan mengupayakan realisasi COC di LTS dengan ASEAN sebagai fasilitator dialog (Chongkittavorn 2012). Aturan yang eksplisit dalam kerangka multilateral sangat dibutuhkan guna mencegah penggunaan kekerasan. Di samping itu, Thailand sebagai negara koordinator hubungan ASEAN-Tiongkok periode Juli 2012-2015 mendukung kerja sama multilateral Tiongkok dengan Asia Tenggara.

Malaysia: pragmatisme ekonomi. Dalam dialog informal TiongkokASEAN terkait isu LTS, Malaysia mendukung preferensi Tiongkok untuk tidak menginternasionalisasi konflik ini (Odgaard 2003, 15). Sementara dengan kekuatan-kekuatan regional maupun eksternal, Malaysia lebih memilih untuk pragmatis, yakni dengan tetap membangun kerja sama ekonomi dengan Tiongkok dan kerja sama militer dengan AS. Pada tahun 2009, setelah Malaysia mengukuhkan klaimnya ke LTS bersama dengan Vietnam, Tiongkok dan Malaysia membentuk Join Action Plan on Strategic Cooperation yang kemudian merambah sektor ekonomi. Pada tahun tersebut, perekonomian Malaysia sedang dalam penurunan, berbanding terbalik dengan Tiongkok (Finkbeiner 2013, 10-12). Mengacu data IMF, Malaysia mengalami penuruan pertumbuhan ekonomi dari 4,6\% pada tahun 2008 menjadi $-1,7 \%$ pada tahun 2009, sementara Tiongkok memiliki pertumbuhan ekonomi sebesar 8,7\% pada tahun 2009 (Bank Negara Malaysia 2009, 4). Di sini terlihat pragmatisme Malaysia yang mengesampingkan isu kedaulatannya di LTS demi kepentingan ekonomi.

Dari segi militer, Malaysia tidak menganggap tindakan Tiongkok di area sengketa sebagai suatu ancaman serius. Hal itu ditunjukkan dengan alokasi anggaran belanja militer Malaysia yang cenderung menurun dari tahun 2008 ke tahun 2010 dan cenderung statis tahun-tahun setelahnya (Trading Economics 2016). Pada tahun 2008 sampai 2010, anggaran militer Malaysia terus menurun, yaitu dari $\$ 4348,5$ juta, $\$ 4105$ juta, 
kemudian $\$ 3.585,8$ juta. Anggaran militer selanjutnya berturut-turut sebesar \$4.018 juta (2011), \$3833 juta (2012), \$4177 juta (2013), \$4202 juta (2014), \$4532 juta (2015), \$4295 juta (2016). Meski demikian, sektor militer Malaysia memiliki ikatan kerja sama yang cukup erat dengan AS. Sejak peristiwa 11 September 2001, AS menargetkan Malaysia untuk mendukung kebijakan War on Terror dengan adanya Memorandum of Understanding on Counter-Terrorism pada tahun 2003 dan Acquisition and Cross-Servicing Agreement di tahun 2005 (Finkbeiner 2013, 14-15).

Brunei: cenderung pasif. Brunei Darussalam adalah pihak yang paling pasif di antara negara pengklaim lainnya. Brunei tidak berusaha menunjukkan kekuatan militernya di area sengketa (Odgaard 2003, 18). Kebijakan yang tidak bersifat konfrontatif tersebut merupakan hasil pertimbangan akan kapasitas pertahanan yang kurang memadai dan kondisi sumber daya hidrokarbon yang diprediksi akan segera menipis dalam waktu dekat. Padahal, saat ini, hasil dari sumber daya hidrokarbon merupakan 90\% dari total pendapatan hasil ekspor Brunei, sehingga menjalin kerjasama energi yang cukup besar dengan Tiongkok menjadi esensial bagi Brunei (Heydarian 2012). Selama ini, Tiongkok bukan hanya konsumen utama dan pemilik teknologi pengeboran lepas pantai, namun juga pasar potensial bagi Brunei sebagai alternatif sumber pendapatan yang bergantung pada hidrokarbon. Selain itu, merosotnya GDP Brunei pascakrisis finansial global 2009 juga mendorong pasifnya sikap Brunei dalam kasus LTS.

Ketika ketua ASEAN berpindah tangan ke Brunei di tahun 2013, Brunei menunjukkan sikap netral dengan mendukung prinsip shelving disputes and pursuing joint development yang diusung oleh Tiongkok dan menghindari kebijakan konfrontatif. Pada bulan Desember 2013, misalnya, Brunei menolak untuk menghadiri pertemuan informal yang diadakan Filipina untuk negara pengklaim dari ASEAN. Selain itu, Brunei memutuskan untuk tidak mengadakan pertemuan anggota guna membahas isu-isu penting selama satu tahun terakhir lantaran khawatir bila kasus LTS akan menjadi topik utama dan memicu konfrontasi (Zhida 2013).

Kamboja: menghindari kebijakan konfrontatif. Dalam pembahasan sengketa LTS, Kamboja yang tidak punya kepentingan secara langsung lebih sering mengikuti suara mayoritas dan jarang mengemukakan pendapatnya. Meski pada tahun 2002 Kamboja sebagai ketua ASEAN memiliki prestasi dalam mempersuasi Tiongkok untuk menyepakati 
DOC, namun pada edisi tahun 2012, perhatian Kamboja mengenai isu LTS cenderung menurun (Sarith 2013). Keputusan Kamboja yang tidak mengagendakan isu LTS pada pertemuan puncak ASEAN di bulan April 2012 mengundang reaksi beragam dan memunculkan prasangka bahwa Kamboja memihak dan menjadi boneka Tiongkok (Chen 2012). Menurut Vietnam, isu LTS terlalu penting untuk tidak diagendakan dalam pertemuan puncak ASEAN. Sementara itu, Malaysia menyatakan bahwa keputusan Kamboja cukup masuk akal, mengingat beberapa negara anggota ASEAN memiliki hubungan dekat dengan Tiongkok. Pembahasan terusmenerus mengenai topik ini dapat menjadi hal yang provokatif. Melalui surat klarifikasi juru bicara Kementerian Luar Negeri dan Kerjasama Internasional Kamboja kepada media, Kamboja menyatakan bahwa negara itu memiliki posisi dan prinsip dalam bertindak sebagai negara merdeka. Pada dasarnya, Kamboja tidak ingin ASEAN Ministerial Meeting (AMM) didominasi permasalahan bilateral. Di samping itu sudah sepantasnya Kamboja sebagai ketua ASEAN mencegah situasi yang telah memanas agar tidak menjadi lebih parah (Kuong 2012). Pada kepemimpinannya di tahun 2012, Kamboja bahkan menekankan bahwa pemimpin ASEAN telah menyepakati untuk menolak internasionalisasi konflik, yang mana diketahui bahwa keputusan tersebut tidak berdasarkan konsensus (Loy 2012). Hal tersebut diduga dipengaruhi oleh peristiwa pada tahun 2010, ketika Wen Jiabao menemui Samdech Hun Sen dan menjanjikan bantuan ekonomi agar Kamboja bersedia menolak internasionalisasi isu LTS (Shoji 2011, 19).

Myanmar: condong pada Tiongkok dan beban sanksi internasional. Tanpa kepentingan secara langsung di area sengketa, Myanmar pada dasarnya hanya mengikuti apa yang menjadi keputusan mayoritas dalam forum ASEAN sembari bermanuver di antara kekuatan-kekuatan besar yang berkepentingan di LTS. Myanmar berada pada kubu oposisi terhadap keterlibatan AS di kawasan karena alasan sanksi ekonomi, dan dengan demikian lebih memilih untuk cenderung kepada Tiongkok. Peningkatan kerja sama militer dengan Tiongkok menjadi salah satu bukti posisi Myanmar. Pada tahun 1992, Tiongkok memberikan bantuan finansial dan teknis untuk pembangunan pangkalan angkatan laut di Pulau Hainggyi. Sebagai timbal balik, Tiongkok memperoleh akses untuk menggunakan fasilitas di pangkalan tersebut (Selth 2007, 5). Pada tahun 2011, posisi Myanmar diperjelas dengan pernyataan Thein Sein akan dukungannya terhadap posisi Tiongkok dalam sengketa LTS saat kunjungannya ke Tiongkok (Shoji 2011, 19). 
Laos: "land-lockedcountry"yang rentanpengaruh Tiongkok. Kepentingan Laos dalam isu LTS sangat minim. Laos termasuk negara anggota ASEAN yang jarang bersuara. Terlepas dari pernyataan Menteri Luar Negeri Laos akan pentingnya isu LTS dan pembentukan COC untuk menyelesaikan permasalahan dan menjaga perdamaian, Laos termasuk negara dengan perkembangan tertinggal di ASEAN dan membutuhkan investasi Tiongkok (Thayer 2012). Selama dua dekade terakhir, Tiongkok telah menanam investasi di Laos yang pada tahun 2011 mencapai \$3 miliar, diantaranya melalui pembangunan destinasi wisata dan pengadaan rel kereta api yang akan menghubungkan Vientiane dengan Kunming (Tran \& Duc 2013; Penna 2013). Meski Laos belum menyatakan secara langsung mengenai dukungannya terhadap Tiongkok seperti Myanmar dan Kamboja, dengan besarnya pengaruh Tiongkok di Laos, tidak menutup kemungkinan bila Laos akan semakin tergantung pada Tiongkok dan menjadi salah satu pendukung posisinya dalam kasus sengketa LTS.

\section{ASEAN yang Terbelah}

Dari reaksi di atas, dalam isu LTS, negara anggota ASEAN terbelah menjadi tiga perbedaan pilihan strategi menghadapi Tiongkok. Strategi pertama, negara anggota ASEAN yang cenderung menunjukkan perilaku ke arah strategi perimbangan atau balancing, yaitu Filipina dan Vietnam. Sebagai negara pengklaim, mengalah pada agresivitas Tiongkok di wilayah klaimnya bukan pilihan bagi Filipina dan Vietnam. Upayaupaya Filipina dan Vietnam dalam mempertahankan kedaulatan di area sengketa menunjukkan bahwa kedua negara ini tengah meningkatkan kekuatannya demi perolehan keamanan di LTS. Dengan kecurigaan dan kekhawatiran akan potensi Tiongkok perihal militer, kedua negara ini terus mempersiapkan diri menghadapi skenario terburuk. Hal ini ditunjukkan, misalnya, ketika Filipina melibatkan AS untuk mendukung peningkatan kapasitas militernya, dan ketika Vietnam telah menempatkan 700 personil militer di area klaimnya sejak tahun 1999. Kebijakan tersebut membuktikan bahwa Filipina dan Vietnam memandang persoalan sengketa LTS dengan pemikiran realisme ofensif.

Denganpertimbangandaripemikiranrealismeofensifdanpergeseransistem internasional pasca-Perang Dingin, Filipina dan Vietnam menunjukkan kecondongan ke penerapan strategi balancing. Situasi Filipina dan Vietnam berada pada situasi pendorong yang dikemukakan oleh Walt. Pertama, tingkat kepercayaan rendah, yang ditunjukkan dengan sejarah hubungan 
bilateral keduanya yang tidak berjalan mulus. Kedekatan Filipina-Taiwan selalu menjadi pengganjal dalam hubungan Tiongkok-Filipina, sementara Vietnam yang dalam sejarahnya pernah menolak keberadaan Tiongkok di negaranya selama 900 tahun juga hanya memiliki hubungan bilateral yang meningkat secara gradual. Karena tindakan unilateral Tiongkok di area sengketa yang kerap melanggar kesepakatan bilateralnya dengan Filipina dan Vietnam serta peningkatan kapasitas militer Tiongkok yang konstan dari tahun ke tahun, maka mempercayai Tiongkok dianggap sebagai hal yang beresiko. Sebelumnya, kesepakatan bilateral antara Tiongkok dan Fipilina pasca-insiden Gugusan Karang Mischief 1995 dilanggar dengan tindakan-tindakan Tiongkok di Gugusan Karang Mischief ke-II maupun Beting Scarborough (Chung 2009, 98). Kesepakatan bilateral VietnamTiongkok mengenai batas maritim dan kerjasama perikanan di Teluk Tonkin dilanggar dengan tindakan pelarangan menangkap ikan secara sepihak oleh Tiongkok (Tønnesson 1991, 57-70). Kedua, perihal kapasitas nasional. Secara militer kemampuan Filipina dan Vietnam memang belum dapat mengimbangi Tiongkok. Namun dengan kerja sama keamanan dengan kekuatan eksternal, kedua negara ini memperoleh dukungan dari segi presensi maupun secara materiil. Sementara dari segi ekonomi, Filipina dan Vietnam terhitung memiliki ketergantungan lebih rendah terhadap Tiongkok dibanding dua negara ASEAN pengklaim lainnya. Sektor agrikultur yang menjadi keunggulan Filipina tidak membutuhkan Tiongkok sebagai destinasi ekspor. Pasar produk agrikultur Filipina adalah AS, Jepang, Belanda, Korea Selatan, Thailand, Malaysia, dan Vietnam (Senate of the Phillippines \& Senate Economic Planning Office 2012). Aktivitas perdagangannya lebih didominasi oleh AS dan Jepang. Sementara itu, setelah masuk WTO, perkembangan ekonomi Vietnam tercatat terus meningkat dan stabil (World Bank 2017). Kerja sama ekonomi bilateral Vietnam lebih kuat dengan AS melalui U.S and Vietnam Trade and Investment Framework Agreement (TIFA) ketimbang dengan Tiongkok melalui ASEAN-China Free Trade Agreement (ACFTA). Terakhir, mengenai ketersediaan koalisi, Filipina memperoleh dukungan AS, sementara Vietnam telah meningkatkan kapasitas internalnya dengan dukungan Rusia.

Strategi kedua, negara anggota ASEAN yang menunjukkan kecenderungan perilaku strategi pemihakan terhadap negara yang lebih kuat atau bandwagoning, yaitu Kamboja, Myanmar, dan Laos. Ketiga negara ini pada dasarnya tidak begitu terganggu dengan tindakan Tiongkok di kawasan karena tidak terlibat langsung dalam kasus sengketa. Dengan kedekatan hubungannya dengan Tiongkok, pada dasarnya ketiga negara 
ini sudah cukup puas dengan situasi yang ada. Sejumlah perilaku seperti dukungan terhadap posisi Tiongkok di area sengketa oleh Myanmar, maupun dukungan penolakan internasionalisasi konflik oleh Kamboja, menunjukkan upaya maksimalisasi keamanan posisinya terhadap Tiongkok. Kamboja, Myanmar, dan Laos menunjukkan kebijakan menghindari konfrontasi guna mempertahankan situasi yang sudah dianggap menguntungkan dan terus membuka pintu kerja sama dengan Tiongkok. Perilaku menghindari kebijakan konfrontatif supaya situasi tetap bertahan sebagaimana adanya dan terus mengupayakan peningkatan keamanan lebih melalui tindakan tersebut menunjukkan bahwa Kamboja, Myanmar dan Laos memandang isu sengketa LTS dengan lensa realisme defensif.

Didorong oleh pemikiran realisme defensif dan pertimbangan pada pergeseran sistem internasional, Kamboja, Laos, dan Myanmar menunjukkan sikap yang condong ke arah penerapan strategi pemihakan atau bandwagoning dengan Tiongkok. Pernyataan ini didukung dengan tiga situasi pendorong penerapan strategi bandwagoning. Pertama, terkait isu kepercayaan, yang mana pengaruh Tiongkok sangat besar dalam perkembangan masing-masing negara ini. Banyaknya proyek pembangunan dan investasi di Kamboja, Myanmar, dan Laos yang didominasi oleh Tiongkok menunjukkan tingkat kepercayaan yang cukup tinggi antara tiga negara ini dengan Tiongkok. Dari sisi sejarah, Kamboja telah memiliki ikatan dengan Tiongkok semenjak masa isolasi Tiongkok dengan menunjukkan dukungan aktifnya. Laos dengan stabil mengalami peningkatan kedekatan dengan Tiongkok semenjak terbangunnya hubungan diplomatik yang diperkuat dengan pernyataan bersama di tahun 2000. Myanmar membangun kedekatannya dengan Tiongkok melalui kerjasama pascasanksi internasional 1988. Hubungan kepercayaan keduanya dicerminkan melalui panggilan "Paukphauw" yang ditujukan hanya untuk satu sama lain. Kedua, dari segi kapasitas nasional, Kamboja, Myanmar dan Laos merupakan tiga negara anggota ASEAN dengan daya saing yang rendah. Dalam Global Competitiveness Report 2016-2017, Kamboja, Myanmar, dan Laos menempati peringkat ke 89, 139, dan 93 dari total 148 perekonomian dunia (Schwab 2017, xiii). Kamboja juga masih harus berurusan dengan kemiskinan dan peningkatan standar hidup penduduknya, sementara Laos masih bergantung dengan investasi asing. Sedangkan Myanmar masih mengalami efek kesulitan sanksi internasional. Ketiga, terkait ketersediaan koalisi. Bagi ketiga negara tersebut, tidak ada urgensi untuk melawan Tiongkok. Tingginya kepercayaan serta kapasitas nasional yang masih membutuhkan dukungan 
Tiongkok membuat pilihannya untuk berada di pihak Tiongkok menjadi pilihan rasional.

Strategi ketiga, adalah strategi jalan tengah atau middle path untuk menggambarkan posisi beberapa negara anggota ASEAN yang tidak menunjukkan kecenderungan ke arah balancing maupun bandwagoning, yaitu Indonesia, Singapura, Thailand, Malaysia, dan Brunei. Pada dasarnya Malaysia dan Brunei merupakan negara anggota ASEAN yang dapat menerapkan pilihan strategi mana pun terhadap Tiongkok. Meskipun dari aspek kepercayaan, Brunei dan Malaysia memiliki hubungan bilateral yang erat dan ikatan persahabatan dari sejarah yang cukup panjang, namun keterlibatannya secara langsung dalam persengketaan membuat kedua negara ini harus mempertaruhkan kedaulatan bila memutuskan untuk mengambil strategi bandwagoning. Dari segi kapasitas nasional, kedua negara ini bukan negara yang lemah atau tertinggal. Brunei memiliki peringkat yang baik sebagai salah satu negara di dunia dengan tingkat stabilitas makro ekonomi tertinggi di Asia. Selain itu Brunei merupakan produsen minyak terbesar ke-4 di Asia Tenggara dengan rata-rata 167.000 barel per hari di tahun 2009. Sementara itu, Malaysia termasuk sebagai salah satu negara anggota ASEAN yang perkembangan ekonomi cukup bagus. Menurut Global Competitiveness Index 2016-2017, Brunei dan Malaysia menempati peringkat 30 dan 46 dunia (Schwab 2017, xiii). Meski demikian, hubungan bilateral yang erat membuat kedua negara ini tidak menerapkan kebijakan konfrontatif terhadap Tiongkok. Sikap tersebut ditunjukkan ketika Brunei menghindari kebijakan konfrontatif dalam kepemimpinannya sebagai ketua ASEAN, dan ketika Malaysia menunjukkan dukungan terhadap tindakan Kamboja untuk tidak mengagendakan isu LTS dalam pertemuan puncak ASEAN.

Tiga negara ASEAN lain, yakni Indonesia, Singapura, dan Thailand juga tidak menunjukkan kecenderungan ke arah strategi balancing maupun bandwagoning. Ketiga negara ini tidak terlibat secara langsung dalam sengketa LTS sehingga kepentingan yang mendominasi adalah stabilitas regional dan kebebasan navigasi. Berangkat dari kepentingan tersebut, Indonesia, Singapura, dan Thailand memutuskan untuk menunjukkan sikap sebagai pihak yang netral dan memerankan fungsinya sebagai fasilitator. Indonesia menunjukkan peran aktifnya dengan menginisiasikan lokakarya tahunan, merumuskan draf nol kode tata berperilaku, dan mengupayakan persamaan posisi negara anggota ASEAN dengan melakukan shuttle diplomacy. Thailand sebagai negara koordinator hubungan ASEAN-Tiongkok juga menunjukkan dukungannya akan 
eksplorasi kerja sama karena menganggap bahwa peraturan yang eksplisit dalam kerangka multilateral akan membantu menghindari penggunaan kekerasan. Singapura menunjukkan sikapnya yang terus menjaga keseimbangan keterlibatan kekuatan eksternal di kawasan dengan tetap mendorong intensifikasi kerja sama ekonomi Tiongkok-ASEAN sekaligus mendukung kehadiran AS di Asia Tenggara.

Bila menganalisis berdasarkan tiga situasi yang ditawarkan oleh Walt, sebenarnya Indonesia cenderung akan melakukan balancing terhadap Tiongkok karena sentimen sejarah yang masih membawa kecurigaan terhadap Tiongkok. Sementara Singapura dan Thailand cenderung dapat melakukan balancing maupun bandwagoning, lantaran dari segi kepercayaan, kerjasama bilateralnya dengan Tiongkok telah mengesampingkan kecurigaannya terhadap Tiongkok. Dari segi kapasitas, Thailand masuk peringkat 32 menurut segi indeks kompetitif global dari Bank Dunia pada tahun 2017 (Schwab 2017, xiii). Pada tahun 2012, Bank Dunia memindahkan Thailand dari kategori negara dengan pendapatan ekonomi menengah ke ekonomi atas (Jitsuchon 2012, 256). Dari segi militer, Thailand yang masih harus berhadapan dengan pemberontakan muslim di bagian selatan terus melakukan modernisasi sistem pertahanan hingga menguras anggaran sebesar \$5,7 miliar di tahun 2013 . Sedangkan Singapura menduduki posisi 3 besar dalam peringkat Global Competitivenes Index 2016-2017 dengan predikat sebagai destinasi perdagangan asing dan investasi paling diminati setelah Hongkong (Schwab 2017, xiii). Selain itu, pada tahun 2012, Singapura meningkatkan alokasi anggaran belanja untuk senjatanya hingga 24\% mencapai $\$ 9,7$ miliar. Mengenai ketersediaan koalisi, ketiga negara ini memiki hubungan yang relatif baik dengan negara-negara besar di luar kawasan. Namun, untuk memperoleh stabillitas kawasan dan kebebasan navigasi, maka pilihan yang rasional dari ketiga negara tersebut adalah mempertahankan posisi netral dan membantu katalisasi penyelesaian sengketa.

\section{Simpulan}

Pemaparan analisis di atas menunjukkan bahwa negara-negara anggota ASEAN tidak satu kata menghadapi Tiongkok. Namun, heterogenitas ASEAN tidak selamanya menjadi titik kelemahan. Dalam kasus sengketa LTS, perbedaan strategi yang dipilih masing-masing negara anggota ASEAN dalam menghadapi Tiongkok memiliki peranannya masingmasing. Karakter strategi balancing yang dilakukan Filipina dan Vietnam 
dengan membawa pengaruh eksternal dan meningkatkan kapasitas pertahanan dan militernya berperan untuk menahan Tiongkok agar tidak bergerak lebih agresif dari aksi-aksi yang pernah dilakukan di masa lalu. Karakter bandwagoning yang dilakukan oleh Kamboja, Myanmar, dan Laos berperan mempertahankan kedekatan Tiongkok dengan ASEAN. Pasalnya, Tiongkok merupakan negara besar dengan pasar potensial dan teknologi yang berkembang dengan pesat. Totalitas dalam melawan Tiongkok tidak selalu langkah tepat dalam hubungan internasional yang semakin lama saling terkait satu sama lain. Sementara itu, negara-negara middle path dengan posisi yang cenderung netral seperti Indonesia, Singapura, Malaysia, Thailand, dan Brunei memegang peranan sebagai pihak yang mengembalikan fokus ASEAN kepada tujuan bersama dalam menghadapi Tiongkok, yaitu realisasi kode tata berperilaku yang lebih erat dan mengikat.

Dalam penelitian ini, konsep realisme struktural yang digunakan sebagai pendukung argumen utama menjadi titik terang yang menunjukkan bahwa pada dasarnya keamanan merupakan hal yang memiliki beberapa perspektif. Masing-masing pihak memiliki perspektif atau pandangan keamanannya sendiri, yang kemudian mempengaruhi bagaimana pihak tersebut bertindak. Dalam kasus sengketa LTS yang diangkat dalam penelitian ini, pergeseran distribusi kekuatan yang turut merubah sistem internasional menjadi alasan perubahan pandangan setiap aktor internasional di Asia Tenggara mengenai definisi keamanan. Perbedaan strategi negara anggota ASEAN menegaskan bahwasanya ASEAN sebagai organisasi tidak memiliki strategi tunggal dalam menghadapi Tiongkok di LTS. Fungsi-fungsi yang muncul dari perbedaan strategi ASEAN tersebut menjadi keunggulan tersendiri bagi organisasi ASEAN ini dalam menjalankan hubungannya dalam lingkup global. 


\section{Daftar Pustaka}

\section{Buku dan Bab dalam Buku}

Chung, Christopher, 2009. "Southeast Asia and the South China Sea Dispute", dalam Bateman, Sam \& Ralf Emmers (eds.), 2009. Security and International Politics in the South China Sea Towards a Cooperative Management Regime, Routledge. New York: Routledge.

Djalal, Hasjim, 2009. "The South China Sea: The long road towards peace and cooperation”, dalam Bateman, Sam \& Ralf Emmers (eds.), 2009. Security and International Politics in the South China Sea Towards a Cooperative Management Regime, Routledge. New York: Routledge.

Finkbeiner, John, 2013. Malaysia's Great Power Balance and the South China Sea Disputes. Philadelphia: United States Army War College.

Lobell, Steven E., 2010, "Structural Realism/Offensive and Defensive Realism”, dalam Denemark, Robert A. (ed.), 2010. The International Studies Encyclopedia Volume X. UK: Blackwell Publishing Ltd.

Mearsheimer, John J., 2007. "Structural Realism”, dalam Dunne, Tim, Milija Kurki, \& Steve Smith (eds.), 2007. International Relation Theories Discipline and Diversity. New York: Oxford University Press.

Russett, Bruce, 1967. International Regions and the International System; A Study in Political Ecology. Chicago: Rand McNally and Company.

Thayer, Carlyle A., 2013. Indonesia's Efforts to Forge ASEAN Unity on a Code of Conduct. Washington: CSIS.

Walt, Stephen Martin, 2007. "Alliances: Balancing And Bandwagoning", dalam Art, Robert J. \& Robert Jervis (eds.), 2007. International Politics: Enduring Concepts and Contemporary Issues. New York: Pearson/ Longman

Weatherbee, Donald E., 2005. International Relations in Southeast Asia The Struggle for Autonomy. Lanham: Rowman \& Littlefield Publishers, Inc.

Zhiguo, Gao, 2005. "South China Sea: Turning Suspicion into Mutual Understanding and Cooperation", dalam Saw Swee-Hock, Sheng Lijun, and Chin Kin Wah (eds.), 2005. ASEAN-China Relations: Realities and Prospects. Singapura: ISEAS Publishing.

\section{Jurnal dan Jurnal Daring}

Acharya, Amitav, 2017. "The Evolution and Limitations pf ASEAN Identity", dalam Aileen Baviera \& Larry Maramis (eds.), 2017, 25-38. ASEAN@50 Volume 04: Building ASEAN Community: PoliticalSecurity and Socio-cultural Reflections. Jakarta: Economic Research 
Institute for ASEAN and East Asia.

Buszynski, Leszek, 2003. "ASEAN, the Declaration on Counduct, and the South China Sea", Contemporary Southeast Asia, 25(3): 343-362.

Ciorciari, John D., \& Jessice Chen Weiss, 2012. "The Sino-Vietnamese Standoff in the South China Sea", Georgetown Journal of International Affairs, 61-69.

Darmawan, Arief Bakhtiar \& Gebyar Lintang Ndadari, 2017. "Keterlibatan Amerika Serikat dalam Sengketa Laut Tiongkok Selatan pada Masa Pemerintahan Barack Obama”, Jurnal Hubungan Internasional, 6(1).

Haryanto, Agus, \& Arief Bakhtiar Darmawan, 2015. "Sengketa Laut Tiongkok Selatan: Ancaman bagi Komunitas Keamanan ASEAN?", Jurnal Global \& Strategis, 9(2): 277-292.

Lee, Hochul, 2017. "Power Politics Behind the Transforming Geopolitics in East Asia”, East Asia: An International Quarterly, 34(132): 1-14.

Odgaard, Lisolette, 2003. "The South China Sea: ASEAN's Security Concerns About China", Security Dialogue, 34(1): 292-306.

Selth, Andrew, 2007. "Chinese Military Bases in Burma: The Explosion of a Myth”, Regional Outlook Paper of Griffith Asia Institute, No. 10.

Shoji, Tomotaka, 2011. "Vietnam, ASEAN, and the South China Sea: Unity or D iverseness?”, NIDS Security Studies, 14(1): 3-21.

Thayer, Carlyle A., 2012. "ASEAN's Code of Conduct in the South China Sea: A Litmus Test for a Community Building", The Asia-Pacific Journal: Japan Focus, 10(4): 1-22.

Yeneza, Christine Marie, 2012. “The Spratly's Conflict: Foreign Policy Implications to the Peoples' Republic of China and the Republic of the Philippines”, JPAIR Multidisciplinary Journal, 10(1).

\section{Artikel Daring}

Bank Negara Malaysia, 2009. "Economic Developments in 2009" [online]. https://www.bnm.gov.my/files/publication/ar/en/2009/cp01.pdf [diakses 1 Januari 2018].

Chen, Dene-Hern, 2012. "South China Sea Dispute off ASEA N Summit Agenda." The Cambodia Daily [online]. http://www.cambodiadaily. com/archives/south-china-sea-dispute-off-asean-summitagenda-609/ [diakses 2 Januari 2018].

Chongkittavorn, Kavi, 2012. "Thailand Walks A Tightrope on South China Sea" [online]. http://www.nationmultimedia.com/opinion/Thailandwalksatightrope-on-South-ChinaSea-30181423.html [diakses 1 
Januari 2018].

Heydarian, Richard Javad, 2012. "Brunei in the South China Sea Hot Seat" [online]. http://www.atimes.com/atimes/Southeast_Asia/ NL22Ae07.html [diakses 2 Januari 2018].

International Monetary Fund, 2016. "World Economic Outlook Database" [online]. https://www.imf.org/external/pubs/ft/weo/2016/o1/ weodata/index.aspx [diakses 26 Desember 2017].

Kaplan, Robert D., 2011. "The South China Sea is the Future of Conflict.” Foreign Policy [online]. http://www.foreignpolicy.com/ articles/2011/08/15/the_south_ch ina_sea_is_the_future_of_ conflict?page $=0,0$ [diakses 26 Desember 2017].

Penna, Michele, 2013. "Little, Landlocked Laos: Pawn or Pivot in Asia's Future?” Asian Correspondent [online]. http://asiancorrespondent. com/98465/laos-investment-china-asean/ [diakses 2 Januari 2018].

Sarith, Heng, 2013. "A Job Well Done: Cambodia as ASEAN Chair in 2012" [online]. http://www.eastasiaforum.org/2013/01/19/a-job-welldone-cambodia-as-asean-chair-in-2012/ [diakses 2 Januari 2018].

Senate of The Philippines \& Senate Economic Planning Office, 2012. "Philippine Agriculture Exports at a Glance" [online]. http:// www.senate.gov.ph/publications/AG\%202012-02\%20-\%20 Agricultural\%20Exports.pdf [diakses 2 Januari 2018].

Storey, Ian, 2013. "Presentation of Dr. Ian Storey at the Angara Centre Forum on Maritime Disputes." Angara Centre for Law and Economics [online]. https://www. youtube.com/watch?v=EHpsouUaOBw [diakses 27 Desember 2017].

The Associated Press, 2010. "Vietnam's Cam Ranh Base to Welcome Foreign Navies", The Washington Post [online]. http://www.washingtonpost. com/wp-dyn/content/article/2010/11/o2/AR2010110200139.html [diakses 2 Januari 2018].

Trading Economics, 2016. "Malaysia Military Expenditure" [online]. https://tradingeconomics.com/malaysia/military-expenditure [diakses 1 Januari 2017].

Tran, Duvien \& Khanh Vu Duc, 2013. "ASEAN as pawn in great power game" [online]. http://www.atimes.com/atimes/Southeast_Asia/ SEA-02-221113.html [diakses 2 Januari 2018].

World Bank, 2017. "The World Bank in Vietnam" [online]. http://www. worldbank.org/en/country/vietnam/overview [diakses 2 Januari 2018].

Zhida, Jiang, 2013. "Brunei's Burden", China Institute of International Studies [online]. http://www.ciis.org.cn/english/2013-04/16/ 
content_5878251.htm [diakses 2 Januari 2018].

\section{Lain-Lain}

Baviera, Aileen S.P., 1999. "China's Relation with Southeast Asian:Politic Securiy and Economic Interest”, Discussion Paper of Philippine APEC Study Center Network (PASCN), No. 99-17.

Jitsuchon, Somchai, 2012. "Thailand Achieving Social-Economic Development Balance", dalam Yunling, Zhang, Fukunari Kimura \& Sothea Oum (eds.), 2012. Moving Toward a New Development Model for East Asia-The Role of Domestic Policy and Regional Cooperation. Jakarta: ERIA Research Project Report.

Kementrian Luar Negeri RI, 2011. Pidato Presiden: Sambutan pada Acara Penutupan KTT Ke-19 ASEAN. Nusa Dua, Bali: Penulis.

Roberts, Christopher, 2017. “The South China Sea: Beijing's Challenge to ASEAN and UNCLOS and the Necessity of a New Multi-tiered Approach”, RSIS Working Paper, No. 307. Singapore: Nanyang Technological University.

Schwab, Klaus (ed.), 2017. The Global Competitiveness Report 2016-2017. Geneva: World Economic Forum.

Shaohua, Ma, 2006. China's Multilateralism and the South China Sea Conflict: Quest for Hegemonic Stability? Tesis Pascasarjana. Singapore: National University of Singapore.

Thayer, Carlyle A., 2011. "China-ASEAN and the South China Sea: Chinese Assertiveness and Southeast Asian Responses", Paper to international conference on Major and Policy Issues in the South China Sea: European and American Perspectives.

Tønnesson, Stein, 2001. "An International History of The Dispute in the South China Sea", EAI Working Paper, No. 71.

Vaughn, Bruce \& Wayne M. Morrison, 2006. "China-Southeast Asia Relations: Trends, Issues, and Implications for the United States." Congressional Research Service Report for Congress, 4 April. 